\title{
Patterns of response and drug involved in patients with multiple drug hypersensitivity syndrome
}

Inmaculada Doña, Francisca Gomez, Maria Salas, Maria Jose Torres', Carmen Rondon, Paloma Campo, Maria Dolores Ruiz, Leticia Herrero, Maria Auxiliadora Guerrero, Miguel Blanca

From 6th Drug Hypersensitivity Meeting (DHM 6)

Bern, Switzerland. 9-12 April 2014

\section{Background}

Multiple drug hypersensitivity (MDH) has been defined as a hypersensitivity to two or more chemically unrelated drugs. This has been specially studied in IgE-mediated hypersensitivity reactions to antibiotics and more recently in T-cell-mediated reactions. However, studies focusing in MDH in large populations are lacking. The aim of our study was to describe a well-characterized group of patients diagnosed of MDH.

\section{Methods}

We analyzed retrospectively all patients with a confirmed diagnosis of drug hypersensitivity evaluated in our allergy department between January 2005 and December 2010.

\section{Results}

A MDH was diagnosed in 48 (2.41\%) of the 1989 patients evaluated, being 32 females, with a mean age of $50 \pm 14,43$ years. A total of 137 episodes were reported: $80(58.39 \%)$ suggested an IgE-mediated reaction, $37(27 \%)$ a non-immunologic mechanism (cross-reactive to NSAIDs) and $20(14.55 \%)$ a T-cell mediated reaction. The percentage of MHD in patients with IgE-mediated reactions $(9.78 \%)$ was higher compared to those with T-cell mediated reactions (5.23\%) and non-immunologic reactions $(1.91 \%)(\mathrm{p}<0,0001)$. The drugs most frequently involved were dypirone (13.6\%), ciprofloxacin (12.1\%), amoxicillin-clavulanic acid (11.4\%), amoxicillin (10\%), ASA (8.6\%), ibuprofen (7.1\%) and moxifloxacin (5.7\%). Sensitivity to 2 chemically unrelated drugs was diagnosed in 44 patients and to 3 drugs in 4 . The most frequent

Regional University Hospital of Malaga, Allergy Unit, Spain clinical entities were anaphylaxis/shock (42.85\%) and urticaria (34.92\%).

\section{Conclusions}

Patients with IgE-mediated reactions have a higher risk for developing MHD. More studies are needed to confirm this finding.

Published: 18 July 2014

doi:10.1186/2045-7022-4-S3-P138

Cite this article as: Doña et al:: Patterns of response and drug involved in patients with multiple drug hypersensitivity syndrome. Clinical and Translational Allergy 2014 4(Suppl 3):P138.
Submit your next manuscript to BioMed Central and take full advantage of:

- Convenient online submission

- Thorough peer review

- No space constraints or color figure charges

- Immediate publication on acceptance

- Inclusion in PubMed, CAS, Scopus and Google Scholar

- Research which is freely available for redistribution
() Biomed Central 